\title{
A institucionalização da agroecologia no Brasil: trajetórias acadêmicas e laços discursivos*
}

\author{
Jonatta Sousa Paulino** \\ \& Ramonildes Alves Gomes***
}

Resumo: O fomento da atividade produtiva agroecológica no Brasil se dá por meio do trabalho conjunto de um grupo de indivíduos, representantes de discursos e instituições, os quais se constituem como atores-chave para o entendimento das dinâmicas atuais do rural brasileiro. Neste artigo, analisamos a institucionalização do campo agroecológico nacional, focalizando as redes tecidas para sua construção, seus discursos de transformação social, os atores envolvidos e suas implicações na construção das políticas no setor. A perspectiva teórico-metodológica se baseia na Teoria Ator-Rede, de Bruno Latour (2012), consistindo o trabalho de campo na realização de entrevistas semiestruturadas com uma amostra não probabilística de atores do referido campo e na análise de suas trajetórias. Dentre as conclusões principais, destacamos a de que a atividade produtiva agroecológica no Brasil conecta um sistema informal e internacional de contatos transdisciplinares que relaciona pesquisas acadêmicas, prática docente e atividades de extensão, produzindo um movimento de legitimação do campo.

Palavras-chave: Agroecologia. Teoria Ator-Rede. Ciência. Institucionalização. Trajetórias sociais.

\section{The institutionalization of agroecology in Brazil: academic trajectories and discursive ties}

Abstract: The fostering of agroecological productive activity in Brazil occurs through the joint work of a group of individuals, representatives of discourses and institutions, who constitute themselves as key actors for understanding the current dynamics of rural Brazil. In this article we analyze the institutionalization of the national agroecological field, focusing on the networks woven for its construction, its discourses of social transformation, actors and their implications in the construction of policies referred to it. The theoretical-methodological perspective is based on Bruno Latour's Actor-Network Theory (ANT (2012), and the field work consisted of conducting semi-structured interviews with a non ramdom sample of actors from that field and analyzing their trajectories. Among the main conclusions, we highlight that the agroecological productive activity in Brazil connects an informal and international system of transdisciplinary contacts that links academic research, teaching practice and extension activities, producing a movement to legitimize the field.

Key-words: Agroecology. Actor-Network Theory. Science. Institutionalization. Brazil.
* Este artigo foi inspirado na pesquisa para a tese de Jonatta Sousa Paulino, defendida no Programa de Pós-Graduação em Ciências Sociais da Universidade Federal de Campina Grande (UFCG), Campina Grande, Paraíba, Brasil, no ano de 2017, sob a orientação da professora Ramonildes Alves Gomes.

** Jonatta Sousa Paulino é doutor em ciências sociais pelo Programa de Pós-Graduação em Ciências Sociais (PPGCS) da Universidade Federal de Campina Grande (UFCG), Campina Grande, Paraíba, Brasil. Orcid: 0000-00033874-7145. <jonatta.15@bol. com.br>.

*** Ramonildes Alves Gomes é doutora em sociologia pela Universidade Federal de Pernambuco (2005) e pós-doutora pela École des Hautes Études en Sciences Sociales 
(CRBC/Ehess - 2010)

e pela Université

Paris Ouest Nanterre

La Défense (2010),

Paris, França.

Orcid: 0000-0001

5009-9625.

<rnildes@hotmail.

com>.

1. A vertente

científica da

agroecologia

apresenta-se como

nova forma de

aproximação entre

a agronomia e a

ecologia, "[...] isto é,

a disciplina científica

que estuda e

classifica os sistemas

agrícolas desde

uma perspectiva

ecológica, de modo

a orientar o desenho

ou redesenho de

agroecossistemas

em bases mais

sustentáveis"

(Caporal, Costabeber

\& Paulus, 2011: 61).
Introdução

O debate sobre agroecologia no Brasil é explicado com base em três dimensões: em primeiro lugar, como conjunto de práticas produtivas sustentáveis "ecologicamente corretas"; depois, através de uma perspectiva mais abrangente, como enfoque científico que vai além de modelos de agriculturas e que tem por objetivo fortalecer os pilares de transição para as agriculturas alternativas e os modelos de desenvolvimento rural sustentáveis (Petersen, Dal Soglio \& Caporal, 2009; Almeida, 2009); e, em terceiro lugar, enquanto movimento social, como mobilização que funciona a partir de princípios, conceitos e teorias para o fortalecimento dessas práticas no mundo rural.

Assim, no Brasil, ao falar em agroecologia, acabamos por abarcar essas três dimensões. Todavia, o artigo estará focado na perspectiva científica ${ }^{1}$, de forma a compreender as redes que desenharam a institucionalização da agroecologia no Brasil, através da atuação de atores, grupos e instituições, cujas correspondências entre as trajetórias profissionais, não necessariamente lineares ou causais, foram decisivas para o enraizamento da agroecologia no território brasileiro.

\section{Metodologia}

A metodologia adotada está fundamentada na Teoria Ator-Rede de Bruno Latour (2012). O social, segundo assenta a Teoria Ator-Rede, informa sobre um tipo de associação momentânea que se caracteriza pela maneira como se reúnem os atores sociais. O social não é um domínio especial da realidade, e sim um princípio de conexões. Considera-se como social um fluido circulante e, o que antes era visto como de "domínio social", integra agora o conjunto de elementos a serem reunidos, não no que chamamos de sociedade, mas sim em um coletivo. Deste modo, é necessário seguir a continuidade fluida de entidades heterogêneas e a completa descontinuidade entre os participantes das redes. Em vez de adotar uma posição de uma ordem antecipada, nos direcionamos aos atores deixando que eles mesmos apresentem suas próprias categorias e, a partir desse movimento, explicamos como as redes são estabelecidas.

Para o alcance da metodologia foi utilizada como técnica de pesquisa a entrevista semiestruturada - realizadas nos anos de 2015 e 2016, nas cidades de Campina Grande (PB), João Pessoa (PB), Recife (PE) e Belém (PA) -, com algumas perguntas prévias; contudo, os sujeitos integrantes das redes eram livres para divagar sobre suas vidas, focando principalmente suas trajetórias e atuação profissional. 
QUADRO 1

FALAS TRANSCRITAS E ANALISADAS

\begin{tabular}{|c|c|c|}
\hline Nome & Ocupação & Natureza da fala \\
\hline Eros Marion Mussói & $\begin{array}{l}\text { Professor da Universidade Federal de } \\
\text { Santa Catarina. }\end{array}$ & $\begin{array}{l}\text { Entrevista semiestruturada realizada } \\
\text { durante o IX Congresso Brasileiro de } \\
\text { Agroecologia (CBA), em Belém do Pará, } \\
\text { no ano de } 2015 .\end{array}$ \\
\hline Éric Pierre Sabourin & $\begin{array}{l}\text { Pesquisador do Centre de Coopération } \\
\text { Internationale en Recherche } \\
\text { Agronomique pour le Développement } \\
\text { (Cirad) e professor visitante no Centro } \\
\text { de Desenvolvimento Sustentável da } \\
\text { Universidade de Brasília. }\end{array}$ & $\begin{array}{l}\text { Entrevista semiestruturada realizada } \\
\text { durante o IX Congresso Brasileiro de } \\
\text { Agroecologia (CBA), em Belém do Pará, } \\
\text { no ano de } 2015 .\end{array}$ \\
\hline Luiz Antonio Cabello Norder & $\begin{array}{l}\text { Professor no Centro de Ciências } \\
\text { Agrárias da Universidade Federal de } \\
\text { São Carlos e Coordenador do Programa } \\
\text { de Pós-Graduação em Agroecologia e } \\
\text { Desenvolvimento Rural. }\end{array}$ & $\begin{array}{l}\text { Entrevista semiestruturada e } \\
\text { observação de sua fala na Mesa } \\
\text { Redonda "Cursos de agroecologia: } \\
\text { reconhecimento profissional e } \\
\text { seus desafios", ambos durante o IX } \\
\text { Congresso Brasileiro de Agroecologia } \\
\text { (CBA), em Belém do Pará, no ano de } \\
2015 \text {. }\end{array}$ \\
\hline Tatiana Deane de Abreu Sá & $\begin{array}{l}\text { Pesquisadora em agroecologia } \\
\text { na Embrapa Amazônia Oriental } \\
\text { e professora colaboradora nas } \\
\text { Universidade Federal Rural da } \\
\text { Amazônia e Universidade Federal do } \\
\text { Pará. }\end{array}$ & $\begin{array}{l}\text { Entrevista semiestruturada realizada } \\
\text { por meio de chamada de voz online no } \\
\text { ano de } 2016 \text {. }\end{array}$ \\
\hline Francisco Roberto Caporal & $\begin{array}{l}\text { Professor do Departamento de } \\
\text { Educação da Universidade Federal } \\
\text { Rural de Pernambuco (UFRPE) e } \\
\text { membro do Núcleo de Agroecologia e } \\
\text { Campesinato (NAC) desta instituição. }\end{array}$ & $\begin{array}{l}\text { Entrevista semiestruturada ocorrida } \\
\text { em } 2015 \text { no Núcleo de Agroecologia } \\
\text { e Campesinato (NAC)/Universidade } \\
\text { Federal Rural de Pernambuco (UFRPE). }\end{array}$ \\
\hline Maria Virgínia de Almeida Aguiar & $\begin{array}{l}\text { Professora da disciplina de Extensão } \\
\text { Rural e coordenadora da Licenciatura } \\
\text { em Ciências Agrícolas da Universidade } \\
\text { Federal Rural de Pernambuco (UFRPE). }\end{array}$ & $\begin{array}{l}\text { Entrevista semiestruturada ocorrida } \\
\text { em } 2015 \text { no Núcleo de Agroecologia } \\
\text { e Campesinato (NAC)/Universidade } \\
\text { Federal Rural de Pernambuco (UFRPE). }\end{array}$ \\
\hline Laetícia Medeiros Jalil & $\begin{array}{l}\text { Professora de sociologia da } \\
\text { Universidade Federal Rural de } \\
\text { Pernambuco (UFRPE). }\end{array}$ & $\begin{array}{l}\text { Entrevista semiestruturada realizada } \\
\text { na Universidade Federal Rural de } \\
\text { Pernambuco (UFRPE) em } 2015 .\end{array}$ \\
\hline José Geraldo Wizniewsky & $\begin{array}{l}\text { Professor da Universidade Federal } \\
\text { de Santa Maria no Departamento de } \\
\text { Educação Agrícola e Extensão Rural. }\end{array}$ & $\begin{array}{l}\text { Entrevista semiestruturada realizada } \\
\text { durante o LIII Congresso da Sociedade } \\
\text { Brasileira de Economia, Administração } \\
\text { e Sociologia Rural (Sober), em João } \\
\text { Pessoa (PB) no ano de } 2015 \text {. }\end{array}$ \\
\hline Jalcione Pereira de Almeida & $\begin{array}{l}\text { Professor da Universidade Federal } \\
\text { do Rio Grande do Sul, vinculado } \\
\text { ao Departamento de Sociologia } \\
\text { do Instituto de Filosofia e Ciências } \\
\text { Humanas. }\end{array}$ & $\begin{array}{l}\text { Entrevista semiestruturada realizada } \\
\text { durante o LIII Congresso da Sociedade } \\
\text { Brasileira de Economia, Administração } \\
\text { e Sociologia Rural (Sober). }\end{array}$ \\
\hline Paulo André Niederle & $\begin{array}{l}\text { Professor do Departamento de } \\
\text { Sociologia e dos Programas de } \\
\text { Pós-Graduação em Sociologia e em } \\
\text { Desenvolvimento Rural da UFRGS. }\end{array}$ & $\begin{array}{l}\text { Entrevista semiestruturada realizada } \\
\text { durante o LIII Congresso da Sociedade } \\
\text { Brasileira de Economia, Administração } \\
\text { e Sociologia Rural (Sober), em João } \\
\text { Pessoa (PB) no ano de } 2015 .\end{array}$ \\
\hline Jorge Roberto Tavares de Lima & $\begin{array}{l}\text { Professor da Universidade Federal Rural } \\
\text { de Pernambuco (UFRPE), associado ao } \\
\text { Núcleo de Agroecologia e Campesinato } \\
\text { (NAC). }\end{array}$ & $\begin{array}{l}\text { Entrevista semiestruturada realizada } \\
\text { durante o evento "Diálogos de } \\
\text { Conhecimento sobre Agroecologia". }\end{array}$ \\
\hline
\end{tabular}

Fonte: Os autores. 
Os acontecimentos relatados não ocorrem, necessariamente, em sua estrita sucessão cronológica, pois se organizam em sequências ordenadas segundo relações inteligíveis. O relato se baseia na preocupação relacionada ao interesse da pessoa de dar sentido, de extrair uma lógica no dito, variável segundo sua trajetória e sua posição no campo social. Estamos diante de uma criação artificial de sentido, uma história de vida produzida. Esse relato é uma apresentação oficial de si oficializando sua própria vida, seja ela pública ou privada, o que traz coações e censuras específicas, negociações do que pode ou não ser dito e a maneira que os elementos são expostos na fala para que não escapem ao padrão desejável (Bourdieu, 2006).

\section{Primeiros passos \\ para uma nova ciência}

As críticas ao padrão tecnológico dominante no mundo rural vão ficando cada vez mais evidentes a partir da década de 1970, e isso em decorrência à crise econômica e aos altos custos das tecnologias modernas, além das consequências sociais e ecológicas. Este período é caracterizado pela disseminação de discursos ambientais que apoiam instituições e ações em torno de um projeto alternativo de desenvolvimento. Este processo dá início à fomentação de redes, conectando diversas esferas do social e passando adiante os ideais de uma nova forma de relacionamento entre homem e natureza.

A crise ecológica inaugura uma polêmica entre peritos, abrindo novas realidades em disputas. Essas controvérsias abafam as certezas da ciência (Latour, 2004) e faz com que outras formas de conhecimento participem da arena na contenda pelo uso legítimo dos recursos naturais pelas populações autóctones. Portanto,

2. Iniciada na década de 1960, também conhecida como "Modernização Conservadora", a Revolução Verde impulsionou o processo de mecanização no campo, "além de ter como característica a quimificação, que se expressa no uso de fertilizantes, agrotóxicos e sementes selecionadas" (Paulino, 2013: 10) the technological dimension of the agroecological revolution emerges from the fact that contrary to Green Revolution approaches (Altieri \& Toledo, 2011: 598).

Ao tomar como ponto de partida o fato de que a agroecologia, especificamente no Brasil, identifica-se como discurso contrário a todo referencial da Revolução Verde², é importante frisar que os efeitos desta revolução se deram, primeiramente, em nosso país, na Região Sul, o que fez com que o movimento de agriculturas alternativas - precursor da agroecologia - tenha apresentado mais força nesta localidade, como aparece na fala de Paulo André Niederle:

Tem que olhar um pouco o contexto em que se desenvolve a agricultura dos anos 1960, 1970 para cá, após início da Modernização Conservadora, da Revolução Verde. Por que a agroecolo- 
gia, enquanto tal, como a gente compreende no Brasil, teve um desenvolvimento específico no Sul do Brasil? Primeiro, por conta da intensidade do processo de modernização da agricultura, do modo como ele se deu. O projeto da Revolução Verde foi aplicado naquela região de forma muito mais intensa, muito mais abrupta, muito mais rápida e com consequências sociais muito expressivas.

[...]

Acho que tem outro fator de protagonismo nesse processo todo, que são os movimentos estudantis e de juventude. Você teve a influência dos Encontros Brasileiros de Agroecologia, muito capitaneados pelas Federações dos Estudantes de Agronomia, e de Veterinária depois; e dos grupos de agroecologia, porque depois de formadas, essas pessoas passaram a atuar nessas organizações. Foram trabalhar no Movimento dos Trabalhadores Rurais Sem Terra (MST); foram trabalhar no Centro de Tecnologias Alternativas e Populares (Cetap); no Centro Ecológico; e a rede pra formar um movimento, essa rede de organizações já se alimentava da rede que existia nos movimentos estudantis (Paulo André Niederle, João Pessoa, 2015).

A estrutura de relações objetivas, ou quadro de tensões,

é o que vai comandar os pontos de vista, as intervenções científicas, os lugares de publicação, os temas escolhidos e os objetos pelos quais os cientistas se interessam (Bourdieu, 2004b: 60).

Assim, as questões ambientais e agrícolas expressarão os rumos que os profissionais tomarão em suas trajetórias e estratégias de ação coletiva no cenário científico nacional, isto porque, as posições defendidas pelos cientistas só são compreensíveis quando inseridas nos campos aos quais estão vinculados.

O termo agricultura alternativa é um discurso social e remonta à década de 1970, conformado na agricultura de base ecológica e impulsionada por organizações comprometidas com um projeto político. Tal movimento ganha força no país principalmente em 1976, graças ao manifesto ecológico brasileiro "Fim do futuro?", de José Lutzenberger, que servirá de inspiração para pesquisadores, ecologistas e a sociedade no geral.

As primeiras críticas ao processo de modernização na agricultura brasileira foram elaboradas e disseminadas por grupos de intelectuais e profissionais (principalmente engenheiros agrônomos) que denunciavam os impactos negativos dessas tecnologias no meio ambiente por meio de publicações científicas. Este movimento ganhou forma durante as décadas de 1970 e 1980, quando as universidades se 
3. Os GA's eram nacionalmente articulados, na década de 1980, perdendo essa articulação nos anos 1990 e se restabelecendo a partir de 2005, com a construção de espaços de discussão, formação e elaboração de pautas políticas, como o Encontro Nacional de Grupos de Agroecologia (Enga) e a Rede dos Grupos de Agroecologia do Brasil (Rega). Atualmente, a Rega ajuda na elaboração de um projeto político que tenha a agroecologia como eixo central, trabalhando a formação teórica, prática e profissionalizante, através de projetos de pesquisa e extensão rural nas universidades

(Fagundes, Ladiera \& Oliveira, 2013).

4. Em 1988, a Aeasp criou o Grupo de Agricultura Alternativa.

5. Redes que fomentaram a criação dos Centros de Tecnologias Alternativas (CTA's). constituíram como espaços privilegiados para este debate, até mesmo no movimento estudantil, tendo como marco a importância da organização de congressos da organização da Federação dos Estudantes de Agronomia do Brasil (Feab).

Os discursos contrários à Revolução Verde desencadearam nas universidades a formação de vários grupos de estudos e pesquisas em tecnologias e agriculturas alternativas. Com o passar do tempo, as propostas amadureceram e esses estudantes militantes dos movimentos pró-agriculturas alternativas se graduaram, resultando, em muitos casos, na criação de organizações não governamentais (ONGs) (Azevedo, 2011) ou Grupos de Agroecologia $\left(G A^{\prime} s\right)^{3}$, que se tornaram importantes na disputa sobre o modelo tecnológico dentro das universidades. Em outras palavras, alunos das ciências agrárias passam a ter contato com a temática, formando grupos de agricultura alternativa dentro dos cursos de agronomia, estudantes estes que farão parte, posteriormente, de quadros profissionais das organizações não governamentais, dos movimentos sociais e do Estado.

\section{O fio da meada com a mobilização da academia}

No que se refere aos impactos da modernização agrícola, essa pauta começou a ser discutida academicamente na década de 1970, quando a Associação de Engenheiros Agrônomos do Estado de São Paulo (Aeasp) realizou o I Congresso Paulista de Agronomia, em 1977, manifestando a necessidade de repensar a agricultura brasileira ${ }^{4}$. Em 1979, durante o IX Congresso Brasileiro de Agronomia, organizado pela Federação das Associações dos Engenheiros Agrônomos do Brasil (Faeab), percebeu-se uma grande adesão dos militantes de esquerda à agricultura alternativa, por considerá-la um modelo anticapitalista.

Os estudantes de agronomia também resistiram, instaurando os embasamentos da agroecologia no Brasil a partir da década de 1980, através dos Encontros Brasileiros de Agricultura Alternativa (Ebaa) e por profissionais graduados que participavam do Projeto Tecnologias Alternativas da Federação de Órgãos para Assistência Social e Educacional (PTA/Fase) - o que será discutido mais adiante -, formando redes de intercâmbio entre diferentes setores da sociedade ${ }^{5}$.

Nas universidades, os movimentos alternativos eram organizados por estudantes apoiados pela Feab, que se encontravam nos Congressos Nacionais de Estudantes de Agronomia (Conea's). Em 1981, a Feab, a Associação dos Engenheiros Agrônomos do Paraná e o Grupo de Agricultura Alternativa da Aeasp organizaram o I Encontro Brasileiro de Agricultura Alternativa (Ebaa) em Curitiba (PR), configurando um marco 
da agricultura alternativa no Brasil, apresentando uma proposta contrária à Revolução Verde (Padula, Cardoso, Ferrari e Dal Soglio, 2013).

Essa interação institucional entre a rede PTA e o Ebaa foi rememorada pelo o professor Jalcione Almeida, um de nossos entrevistados:

E aí tem que ir lá buscar nos Ebaa's [...]. O primeiro, se não me engano, foi em Curitiba, por causa dessa efervescência do Paraná; o segundo foi no Rio de Janeiro, em que a AS-PTA já estava, ela estava no Rio, está no Rio ainda; a terceira, se eu não me engano, foi no Mato Grosso do Sul, ou em Cuiabá, Mato Grosso do Norte, Mato Grosso, em Cuiabá e a última foi em Porto Alegre em 1988, que eu ajudei a organizar um pouco. Então um pouco esse é o caldo assim de cultura, a gênese talvez dessa chamada agroecologia hoje, não é? (Jalcione Pereira de Almeida, João Pessoa, 2015).

Os universitários adentravam neste universo por meio de movimentos estudantis e acabavam participando da organização de eventos acadêmicos, num misto de atividade acadêmica e militância, cuja dedicação chega a acompanhá-los durante muitos anos:

A minha dissertação, lá na década de 1980, foi naquilo que se chamava agricultura alternativa. Não existia essa terminologia "agroecologia", mas agriculturas alternativas [...]. Eu fazia agronomia na época, terminei agronomia. Enquanto estudante de agronomia, digamos, tinha um certo engajamento nas alternativas à agricultura moderna, sempre fui um crítico da agricultura moderna desde os bancos escolares. O movimento agriculturas alternativas na época foi uma válvula de escape, foi uma saída normal que eu encontrei. Foi isso, acho, que até mesmo ajudou a montar os Ebaa's, os Encontros Brasileiros de Agricultura Alternativa, quatro Ebaa's. Na verdade, não os quatro, principalmente os dois últimos e o último em particular que foi em Porto Alegre, o IV Ebaa, acho que foi em 1988, se eu não me engano, que eram referências, assim, nacionais, pontos críticos, assim, dessa agricultura, digamos, moderna e tal.

$[\ldots]$

Esse engajamento, ainda na graduação, me motivou a escolher o tema no mestrado que foi na agricultura alternativa também, eu defendi uma dissertação com esse tema, que modéstia à parte, foi uma dissertação que até hoje é reconhecida como uma das primeiras referências nesse campo da alternativa.

$[\ldots]$

Aí eu fui para o doutorado logo em seguida. E trabalhei, na época, com agriculturas diferentes, um pouco fugindo ao padrão dessa agricultura convencional moderna. E a minha tese, de certa forma, 
também lidou um pouco por aí, mas não trabalhando ainda com agroecologia na verdade. Eu só fui me envolver com agroecologia quando voltei do doutorado, isso em 1993, que aí, tratava-se, o que se pode dizer assim, um movimento nascente enquanto agroecologia (Jalcione Pereira de Almeida, João Pessoa, 2015).

As redes que compõe o movimento de agriculturas alternativas se tornarão a base da institucionalização da agroecologia no Brasil. Tais redes parecem ser extensas e racionalizadas, uma vez que os atores que adentraram nesse campo exibiram certo acúmulo de capital científico e político (envolvimento em atividades acadêmicas e em movimentos sociais), o que faz com que eles estejam "preparados" para participar desse universo, que, como todo e qualquer campo social, envolve competição entre seus participantes com o sucesso de alguns e o afastamento daqueles que não apresentaram as capacidades necessárias para fazer parte.

O II Ebaa ocorreu em 1984 na cidade de Petrópolis (RJ). Deixando como legado a "Carta de Petrópolis - protocolo de intenções", que estabelecia o apoio dos governos estaduais a essas práticas diferenciadas. A partir da mobilização de estudantes e alguns professores apoiados pela Feab, naquele mesmo ano foi aprovado um novo currículo mínimo para os cursos de agronomia, agora incluindo conteúdo das ciências sociais e do meio ambiente, formando um profissional teoricamente mais crítico e comprometido com a realidade rural.

Em 1987 foi realizado o III Ebaa, na cidade de Cuiabá (MT). Agora, o pequeno produtor passa a ser considerado o foco das ações da agricultura alternativa. No IV Ebaa, em 1989, houve um desentendimento e o PTA/Fase saiu da organização. O motivo para a controvérsia foi: enquanto a rede PTA procurava inserir a participação dos agricultores, os outros congressistas queriam manter o encontro num nível mais acadêmico/científico. Assim, os anos 1990 vivenciaram o fim dos Ebaa's e um contexto político desfavorável aos movimentos sociais após a eleição de Fernando Collor de Mello, apagando um pouco a agricultura alternativa, que acabou ficando mais restrita aos Grupos de Agricultura Ecológica de certas universidades (Luzzi, 2007).

Os Ebaa's fincaram o movimento de agriculturas alternativas no cenário acadêmico sulista, servindo como conexão que relaciona diversas histórias de vida em torno da mobilização de estudantes que, posteriormente, se reconectariam em diversas instâncias em razão a esse contato inicial.

Mesmo com o aspecto político e militante de seus atuantes, ligados a diferentes organizações rurais, este movimento também foi impulsionado por pessoas envolvi- 
das com o campo científico e assim continuou por alguns anos, mixando diferentes trajetórias, como a da professora Virgínia Aguiar:

Eu tinha contato com a Fase também, mesmo na época que a gente era estudante e construiu o III Ebaa, a gente tinha contato com o pessoal dos movimentos sociais [...]. Então, era uma rede bem interessante (Maria Virgínia de Almeida Aguiar, Recife, 2015).

Assim, o movimento agriculturas alternativas, que já surge num misto de ciência e militância, de uma academia politizada com profissionais participando de diferentes instituições que procuravam mudar a realidade do campo, ainda deve ser considerada como um braço de novas proposições do saber e de novos fazeres da universidade, pois é nela que surgem as definições e categorizações teórico-científicas e parte da visibilidade nacional e política para legitimar o movimento.

Sobre isto, vejamos um pouco da trajetória do professor Francisco Roberto Caporal, outro grande expoente do assunto:

Bom, eu sou engenheiro agrônomo, formado na Universidade Federal de Santa Maria, em 1975, no auge da Revolução Verde, e fui trabalhar na Extensão Rural do Rio Grande do Sul, naquela época Associação Sulina de Crédito e Assistência Rural (Ascar) - hoje Emater - e fui direto para o campo, trabalhar na assessoria dos agricultores. Na época, a nossa base era o difusionismo, práticas da Revolução Verde, usando dos pacotes da Revolução Verde e, enfim, trabalhei em extensão rural durante 30 anos. De 1988 a 1991, fiz um mestrado de extensão rural em Santa Maria e aí, nessa época, um pouco antes do mestrado, eu estava engajado, na época havia uma luta dos engenheiros agrônomos em defesa do que nós chamávamos de "agricultura alternativa". E a gente realizou vários Encontros Brasileiros de agricultura alternativa (Ebaa's) e por aí eu fui me engajando nessa luta, como presidente da Associação dos Engenheiros Agrônomos de Santa Maria, a gente construiu a Primeira Lei de Agrotóxicos do Brasil, controle dos agrotóxicos e depois serviu como base para a lei estadual, a primeira lei estadual do Rio Grande do Sul e que, posteriormente, subsidiou a Lei Federal de Agrotóxicos. Então, por aí eu fui tendo contato com essa área, participava também das Comunidades Eclesiais de Base [...]. Nesse período, eu tive contato com o primeiro livro de agroecologia que foi traduzido no Brasil, foi o livro do Miguel Altieri, traduzido pela AS-PTA, que era justamente, na época o título era Agroecologia, bases para uma agricultura alternativa, que depois, na segunda edição, trocou o título e ficou Bases para uma agricultura sustentável. Já estava em moda a ideia do desenvolvimento sustentável e da agricultura sustentável. Bom, por aí eu comecei a escrever alguns artigos já tomando 
6. Arquitetou-se um conjunto de princípios para se chegar ao desenvolvimento sustentável. São eles: reconhecer a diversidade biológica e cultural, fortalecer as capacidades das comunidades e promover a participação civil na gestão dos recursos naturais (Sachs, 1982 apud Leff, 2006). por base as referências do Miguel Altieri (Francisco Roberto Caporal, Recife, 2015).

Como exposto em sua entrevista, o desenvolvimento e a agricultura sustentável já estavam presentes na década de 1970, seguindo o mesmo itinerário veio o discurso do ecodesenvolvimento ${ }^{6}$. Essas ideias e esses conceitos possibilitaram o surgimento da noção de agroecossistema - que só ganhou amplo uso anos depois -, que era considerado como ecossistemas domesticados, um intermédio entre o sistema natural e o fabricado.

\section{A "Armada Cordobesa": tecendo fios e desafios}

O aporte teórico da agroecologia recebeu influências de diferentes áreas do conhecimento - agronomia, ecologia, antropologia e sociologia -, sendo considerado como campo emergente e transdisciplinar. Segundo Lucimar de Abreu e Stéphane Bellon (2014), a matriz conceitual agroecológica se correlaciona a três universidades:

- Universidade de Berkeley, onde Miguel Altieri ministra seus cursos, na Califórnia (Estados Unidos);

- Universidade de Santa Cruz, onde se encontra Stephen Gliessman, na Espanha;

- Universidade de Córdoba, na Andaluzia, também na Espanha.

A evolução do trabalho empírico do Instituto de Sociologia e Estudos Camponeses (Isec), criado em 1978 na Universidade de Córdoba, fomentou uma articulação entre ciências sociais e metodologias participativas do campo da educação. Foi esta

escola de pensamento que introduziu no conceito de agroecologia o sentido sociopolítico de desenvolvimento da agricultura, vinculando-o aos processos históricos, resultado da crítica social ao atual contexto do neoliberalismo e da globalização (Abreu \& Bellon, 2014: 8).

As pesquisas desse instituto relativizaram a epistemologia e a estrutura de poder científica, dando valor ao conhecimento local.

É importante destacar as pesquisas coordenadas por Eduardo Sevilla Guzman, da Universidade de Córdoba, na Espanha, e as conexões entre ele e Miguel Altieri. Essas articulações acadêmicas se consolidaram com a criação do Programa de Pós- 
-Graduação em Córdoba, com o doutorado em "Agroecologia, sociologia e desenvolvimento rural sustentável", em 1991.

Uma conexão clara entre a institucionalização da agroecologia no nosso país e as redes de interação entre o global e o local envolvendo diferentes temporalidades discursivas se deu com a ida de vários profissionais para Córdoba, na Espanha, com o intuito de realizar suas pós-graduações nesta área, como vemos nesta fala de Francisco Caporal:

Em 1994 eu tive a oportunidade de ir para o doutorado, eu escoIhi o curso na Espanha, o programa era justamente "Agroecologia, campesinato e história", que estuda sociologia, na Universidade de Córdoba, e foi como de fato eu entrei nesse tema. Aí, eu tive contato com a maioria dos professores dessa área, que, na época, já estavam militando: Stephen Gliessman, o Alier, o Vítor Toledo, o próprio Miguel Altieri e a Clara, a esposa dele, o Woodgate, da Inglaterra, o Peter Rousseau, dos Estados Unidos, enfim. Todo, praticamente, todo o povo que estava trabalhando com a gente teve contato lá [...] na Espanha. Porque além das disciplinas do doutorado, a gente tinha, já naquela época, um curso de mestrado em agroecologia que reunia todo esse pessoal e continua reunindo até hoje. Então, foi por aí a minha entrada nesse campo. Eu fui orientando do professor Eduardo Sevilla Guzmán, coordenador do doutorado, que também é um expoente nessa área (Francisco Roberto Caporal, Recife, 2015).

Na Espanha, estes estudiosos encontravam o laço entre a produção, principalmente americana, na área de agroecologia - e que mais tarde se tornaria "clássica" - e um programa de formação profissional inteiramente voltado para esta área e em completa sintonia com suas trajetórias profissionais até aquele momento.

A aproximação da agronomia com a ecologia começa com, eu acredito que os precursores foram o Steven Glizman, pesquisando no México, com comunidades indígenas, e o Miguel Altieri pesquisando no Chile também com comunidades indígenas. Baseio-me nas leituras que fiz, me baseio nisso.

[...]

Eles publicaram os primeiros livros em 1988, 1990 e essa bibliografia foi pioneira na área, junto com outros autores: Vandemir, o próprio Peter Rousseu e outros autores que já publicaram nessa época aí. Em seguida, nós vamos ter outra influência importante da Espanha, que é lá do Instituto da Sociologia, com a publicação de um livro do professor Sevilla Guzman junto com Manoel Gonçalez de Molina, eles publicam o livro que também vai ter uma influência grande nessa área. [...] Bom, também naqueles cursos de 
mestrado que ocorriam lá na Espanha, desde 1993-1994, muitos brasileiros e latino-americanos participavam, porque no início o curso era voltado para a América Latina, e como tinha bolsa para todo mundo, naquela época era uma fartura de bolsa, então ia muita gente daqui da América Latina e do Brasil para fazer o curso lá, fazer esse mestrado na Espanha (Francisco Roberto Caporal, Recife, 2015).

7. Diferentemente da categoria de "agroecólogo", que indica os profissionais especializados em agroecologia, principalmente os técnicos desta área tal neologismo serve para tratar, neste trabalho, dos profissionais, não importando a área de formação, que, de alguma forma, já se debruçaram sobre a temática da agroecologia.
O grande fluxo de agroecologistas ${ }^{7}$ nesta ponte entre Brasil e Espanha instaura um cenário científico conformado por relações pessoais, sendo os pioneiros deste movimento os agrônomos do Rio Grande do Sul. Identificamos então duas conexões na rede agroecológica: a primeira delas - efetivada na atividade extensionista - na qual diversos agrônomos que já se conheciam e acabariam escolhendo um mesmo caminho, isto é, o aperfeiçoamento intelectual fora do país; o que nos leva à segunda: as interações que aconteceram na cidade de Córdoba, que influenciaram na conformação de um grupo de pesquisadores mobilizados para um mesmo objetivo.

Estes atores passam por constantes agrupamentos e reagrupamentos para a formação de um grupo, através da energia actante que era investida em sua agregação:

Embora muitos não tenham feito a dissertação, mas beberam lá, porque, como eu disse, passava toda essa turma de agroecólogos por lá como professores, e ainda continua passando. Então eu acho que é por aí que entra a agroecologia na perspectiva mais científica aqui na América Latina. Aqui, no Brasil, na primeira leva nós éramos: Costabeber, Costagomes, Canuto, José Geraldo, Borba, eu, Virgínia. Éramos pelo menos uns dez brasileiros que saímos do doutorado, fomos os primeiros a defender tese no doutorado da Espanha, inclusive antes que os espanhóis. Quando a gente voltou, a gente trouxe essa bagagem que a gente conseguiu construir lá. A bibliografia que a gente também teve acesso durante o doutorado e isso aí serviu de base pra introduzir aqui também esse debate da agroecologia, tanto por dentro da Embrapa, no caso do Costagomes, do Marcos Borba, do Canuto, que são todos pesquisadores da Embrapa, como na Extensão Rural, no caso o Costabeber, eu, o Eros, a galera da Extensão Rural (Francisco Roberto Caporal, Recife, 2015).

A literatura americana reinterpretada na Espanha e trazida para o Brasil faz parte da construção inicial do campo cientifico da agroecologia nacional, que perpassava principalmente a aplicação prática dos aprendizados por meio da extensão rural. Como disse Francisco R. Caporal (em Recife, 2015), 
a América Latina com essa influência da bibliografia espanhola e norte-americana, o Glizman é da Califórnia, o Miguel Altieri, embora tenha pesquisado no Chile, também trabalha na Universidade de Berkeley, na Califórnia (Francisco Roberto Caporal, Recife, 2015).

Outra professora que atualmente trabalha diretamente com Francisco Caporal no Núcleo de Agroecologia e Campesinato da Universidade Federal Rural de Pernambuco, em Recife, é Maria Virgínia de Almeida Aguiar, engenheira agrônoma formada na Universidade Federal do Mato Grosso, com especialização em educação ambiental na mesma universidade. Maria Virgínia Aguiar realizou seu doutorado em agroecologia, história e estudos camponeses em Córdoba. Segundo seu relato, seu contato com a agroecologia:

[...] surgiu no movimento estudantil, só que naquela época, nos anos 1980, a gente chamava de agricultura alternativa e lá na Universidade Federal a gente tinha um centro acadêmico muito atuante, um movimento estudantil atuante ligado à Federação dos Estudantes de Agronomia do Brasil. E a gente levou para lá, em 1987, o III Encontro Brasileiro de Agricultura Alternativa. [...] A gente participou ativamente da construção desse evento. [...] Eu acreditava nos meus colegas também, que eram muito militantes, que tinham um compromisso político muito grande de construção de uma agronomia diferente e essa possibilidade de diálogo que a gente abria - eles né, porque eu me colocava meio à parte - com os movimentos sociais. Então o meu primeiro contato foi através dessa ideia da agricultura alternativa e esse grande evento. Foram quase quatro mil pessoas na época, aí tinha toda uma discussão dos engenheiros agrônomos e dos estudantes de agronomia, então tinha uma forte interlocução desse grupo (Maria Virgínia de Almeida Aguiar, Recife, 2015).

Outro entrevistado que fez seu doutorado em Córdoba foi José Geraldo Wizniewsky. Questionado sobre como havia sido o seu contato com a agroecologia e se ele teria participado das discussões na Espanha no mesmo período que Caporal, respondeu:

Na realidade, antes de me formar na própria faculdade, nos anos 1980, na época não se trabalhava a perspectiva da agroecologia enquanto fonte de conhecimento científico. O que existia era a agricultura alternativa e todos os encontros brasileiros e tal. Então eu me formei em 1984, foi um período de transição do Brasil dos ciclos militares para certa abertura sistemática, que começou emergir; e aí eu me formei e fiquei um ano e meio trabalhando como profissional liberal ligado a algumas ONGs, ligado à igreja, lá no município onde eu nasci, Santa Rosa, no Rio Grande do Sul, 
e trabalhava já junto a umas associações de proteção ao meio ambiente. Foi quando comecei a trabalhar junto aos movimentos sociais. Então a minha trajetória sempre esteve vinculada à ideia da questão agrária, onde sempre trabalhei; movimentos sociais ligados à luta pela terra; e a questão ambiental, que depois sim, eu fiz um mestrado, fiz a minha dissertação fazendo uma crítica a modernização da agricultura justamente no município que era o berço nacional da soja [...]. Eu cheguei no penúltimo ano deles lá, que era o Caporal, o Costabeber, que foi meu colega na universidade, mas já faleceu. Era o Eros Mussói, que trabalha na Empresa de Pesquisa Agropecuária e Extensão Rural de Santa Catarina (Epagri), e agora está só na universidade, se aposentou da Epagri, e tinha o João Carlos Canuto que é lá da Embrapa. E tinha mais outros lá. Depois vem uma nova geração. O Joel, que trabalha na Embrapa em Pelotas (José Geraldo Wizniewsky, João Pessoa, 2015).

Também foi perguntado se o entrevistado teria trabalhado com o professor Francisco Caporal antes do doutorado. Eis a resposta:

Não. Ele entrou dois anos depois do mestrado. Quando eu estava saindo do mestrado ele começava o mestrado em extensão rural. Fui trabalhar na Emater lá. Eu o conhecia superficialmente. O Costabeber sim, eu conhecia, foi meu colega de mestrado e depois a gente compartilhou um ano e meio no doutorado e depois nós estávamos criando um núcleo, que aí eu estou compondo sozinho, um Núcleo de Agroecologia na Universidade de Santa Maria [...]. Lá eles tinham o Gliessman, nos Estados Unidos, trabalhava a agroecologia, mas não era na perspectiva dos assentamentos; o Altieri é a mesma coisa. Seriam as outras alternativas e aí Córdoba abriu essa. E o Sevilla Guzman tinha uma flexibilidade muito grande de pesquisar na América Latina, ele não te impunha pesquisar num projeto lá na Espanha. Então ficava fácil. Eu troquei alguns e-mails por intermediação do Costabeber e do Caporal e aí eu acabei indo em 1997 para lá e fiquei até 2001 (José Geraldo Wizniewsky, João Pessoa, 2015).

Os agroecologistas apresentam trajetórias singulares no que se refere tanto ao aproveitamento das oportunidades surgidas durante a formação acadêmica, quanto da rede de relações e dos lugares ocupados. Este enlace produziu um campo de possibilidades favorável ao próprio crescimento pessoal e, também, a ampliação do espaço da agroecologia. Indagamos sobre o que seria característico do movimento alternativo sulista quando enviou um conjunto de pesquisadores para Córdoba:

Eu acho que talvez um pouco a herança dos, digamos, dos precursores do ambientalismo latino, o Lutzemberger, o Pinheiro, Sebastião Pinheiro. De certa forma, eles deixaram uma inércia do mo- 
vimento ambientalista e também porque Córdoba tinha, de certa forma, um diálogo com o curso de mestrado que nós fizemos em extensão rural, que tinha uma linha ambiental muito forte. Então já abriu discutir a questão de um novo modelo de extensão rural e nesse novo modelo vislumbrar a perspectiva do desenvolvimento rural sustentável, e não se chamava agroecologia; a gente foi se apoderar desse termo efetivamente lá na Espanha. E na realidade, todos os brasileiros que estiveram ajudaram a criar a perspectiva da agroecologia como campo de conhecimento científico, que antes era um programa muito difuso, uns chamavam de prática, e aí começou várias teses a serem feitas reafirmando essa perspectiva, que é um paradigma científico, um campo de conhecimento científico e não uma prática. E aí que se consolidou um grupo que trabalha, digamos assim, dentro dessa perspectiva (José Geraldo Wizniewsky, João Pessoa, 2015).

Portanto, o cenário científico perpassado pelo ambientalismo e pelas novas formas de apropriação da natureza fomentam uma rede de contatos interpessoais - onde os atores utilizavam trajetórias alheias de forma reflexiva para o planejamento de sua própria ação - e definem um coletivo emergente que, em seu retorno ao Brasil, colocariam em prática estratégias de definição epistemológicas para um novo saber e para a construção de políticas públicas em agroecologia, tal como fica evidenciado no diálogo com o professor e cientista social Luiz Norder sobre a institucionalização da agroecologia e seus aspectos científicos e epistemológicos:

É interessante. Córdoba é um paradigma da agroecologia [...]. Então, existem paradigmas de agroecologia. Eu acho que são vários [...]. O de Córdoba é um paradigma que é hegemônico [no Brasil], uma fusão da ciência do movimento social, um discurso de uma ciência voltada para a emancipação, discurso voltado para a fusão entre a universidade e a sociedade, de construção de uma política púbica participativa, com enfoque também científico, respeitando o saber popular. [...] Essa é uma proposição que veio realmente do Costabeber, do Caporal, via Córdoba, Eduardo Sevilla (Luiz Antonio Cabello Norder, Belém, 2015).

A definição de Córdoba enquanto um paradigma brasileiro na agroecologia, envolve uma rede, amarra uma série de atores sociais desde técnicos a um conjunto de instituições (Latour, 2000) na conexão Córdoba-Brasil. Eros Mussói, também entrevistado durante o IV CBA, ao falar sobre a formação dessa rede afirma que:

É uma rede de relações... As pessoas passam a fazer uma rede de relações e surgindo brincadeiras da própria, com relação a Espanha, com relação a Córdoba, a "Máfia Cordobesa" [...], "Armada Cordobesa". O Costagomes que dizia, a "Armada Cordobesa". Sim, por- 
que lá tinha um grupo com o Eduardo Sevilla e que, de fato, foi uma coesão muito grande com esse grupo, entre pessoas que pensavam diferente, mas todo mundo imbuído por uma possibilidade de mudar a sociedade. Então essas pessoas voltam aos seus países. [...] São pessoas que estão em diversos países e que mantivemos relação, trocas, nos encontramos às vezes, então um pouco é isso para te responder, e as pessoas vão se inserindo nas políticas públicas, alguns vão saindo dos ministérios, vão entrando nas universidades, no caso do Caporal e da Virgínia e que ambos estão na universidade e eles continuam articulados (Eros Mussói, Belém, 2015).

Assim, ainda que não haja um consenso sobre o tipo de paradigma que Córdoba inspira no Brasil, a disseminação desse campo resulta, em grande parte, da atuação bem-sucedida de acadêmicos que, graças à posição de vanguarda, ao desejo de se fazerem reconhecer enquanto novos tipos de extensionistas e do intercâmbio profissional necessário para tal, procuraram ampliar a fundamentação científica das práticas agroecológicas através de seus aprendizados na Espanha, funcionando também como diretriz de políticas governamentais e como parte do sistema de educação formal (Norder, Lamine \& Bellon, 2015).

\section{O Projeto Tecnologias Alternativas: amarrando a institucionalização}

Como dito anteriormente, lado a lado com os Ebaa's na construção das raízes da pauta agroecológica no Brasil, havia o Projeto Tecnologias Alternativas (PTA), um projeto, fundado por Jean Marc Von der Weid no âmbito da Federação de Órgãos para Assistência Social e Educacional (Fase), e que mais tarde se tornou independente. O projeto PTA/Fase ofereceu um apoio na luta dos trabalhadores rurais, adentrando em seguida no desenvolvimento de tecnologias com uma dimensão política, buscando trabalhar em parceria com os movimentos sociais. Tal fortalecimento aqui se baseia fortemente no trabalho de José Lutzenberger, Fundamentos ecológicos da agricultura, de 1981.

\footnotetext{
A multiplicação de grupos e associações engajados na busca de técnicas alternativas de produção enseja um encontro em Campinas, em 1983, do qual participam mais de 100 lideranças nacionais entre técnicos e agricultores representantes de diversos estados brasileiros. Neste encontro, foram criadas as bases para a organização de uma rede nacional de fomento às tecnologias alternativas. Surge a partir daí o Projeto Tecnologias Alternativas que se articula em dez estados brasileiros: Maranhão, Ceará, Paraíba, Pernambuco, Bahia, Santa Catarina, Paraná, São Paulo, Rio Grande do Sul e Minas Gerais (Weid, 1985; 1988).
} 
A agricultura alternativa constitui a base para o surgimento de uma rede de organizações não governamentais de cunho desenvolvimentista na agricultura (Brandenburg, 2002: 17).

Os PTA's surgiram a partir da necessidade de organizar as intervenções isoladas de agricultores e ONGs, garantindo a troca de experiências em nível nacional e fomentando, com isso, o movimento em redes no espaço rural. Estes projetos funcionavam junto às Redes de Intercâmbio de Conhecimentos, auxiliando na criação de Centros de Tecnologias Alternativas, espaços para a formação técnica e política dos profissionais atuantes na área, como, por exemplo, para os estudantes das ciências agrárias.

No intuito de fornecer uma maior unidade discursiva para a Rede PTA, no ano de 1988 ocorreu o Encontro Nacional do PTA, que teve como objetivo estabelecer um caráter sistêmico do uso das tecnologias necessárias para alcançar um padrão alternativo de desenvolvimento. Foi com a atuação da Rede PTA que as questões tecnológicas começaram a entrar na pauta dos movimentos sociais com a qual ela se relacionava. Com a Nova República, algumas pessoas próximas ao PTA/Fase passaram a fazer parte do governo, facilitando uma relação estratégica com o Estado na disputa de espaços, recursos financeiros e acesso a instituições de pesquisa, reorientando as políticas públicas para que as ONGs assumissem um papel proeminente.

Jean Marc Von der Weid foi exilado nos anos 1970, indo para o Chile e depois para a França, onde teve contato com tecnologias diferenciadas, trazendo-as para o Brasil, em seu retorno, um elo entre Brasil e França no quesito de propostas alternativas de intervenção social. O exílio passa a ser visto como uma experiência de atravessar fronteiras e mapear novos conhecimentos (Said, 2011). Portanto, foi um dos atores que estabeleceu conexões internacionais para possibilitar a implantação de práticas alternativas na agricultura brasileira.

Em 1989, o Projeto PTA foi reestruturado, a partir da necessidade de organizar-se fora dos quadros institucionais da Fase. Houve então a desvinculação do PTA com a Fase e a constituição de ONGs autônomas, onde os coordenadores do PTA se redistribuíram numa nova instituição, idealizada em 1989 e fundada em março de 1990, a Assessoria e Serviços a Projetos em Agricultura Alternativa (AS-PTA). É neste momento que a agroecologia passa a ocupar a pauta oficial da Rede PTA, procurando conscientizar a sociedade e orientar a política de ação do Estado através da elaboração de programas e projetos que levassem em conta os princípios agroecológicos (Luzzi, 2007). Nos primeiros anos de funcionamento (1989-1992), a AS-PTA atuou como assessoria para instituições membros da Rede PTA, até que, em 1992, os 
membros da AS-PTA assumiram a execução direta de programas de desenvolvimento local. A AS-PTA continuou a prestar serviços para as entidades da Rede PTA, mas priorizou o desenvolvimento de programas mais complexos e com equipes a ela vinculadas.

A Fase foi uma instituição que facilitou a renovação do discurso sobre o desenvolvimento rural associado à sustentabilidade ambiental por meio das tecnologias sociais. Isto significa que tanto a Fase como a AS-PTA conformaram conectores importantes para a agregação de atores engajados nos novos rumos do desenvolvimento do campo. Por mais que o enquadramento não seja de cunho científico, a sua atuação empírica influencia o fazer dos agroecologistas, no geral, e contém elementos globais que explicam a conformação do cenário agroecológico analisado.

O debate francês:

outro paradigma influente

na agroecologia do Brasil

As confluências internacionais tanto da França - por exemplo, o contato cultural de Jean Marc Von der Weid durante seu exílio - como da Espanha marcam o desenvolvimento da agroecologia no Brasil, porém, de forma diferenciada, como discutiremos a seguir. Quanto à concepção da influência francesa na institucionalização do cenário científico nacional, Paulo Niederle afirma:

\begin{abstract}
Essa influência espanhola teve ressonância no meio acadêmico, mas, de novo, comparativamente, eu acho que a influência dela foi maior no âmbito de um grupo de acadêmicos que dialogavam diretamente com a formulação de políticas públicas [...]. E, claro, como uma percepção de agroecologia que era para dentro do meio acadêmico, mas em grande medida, era uma agroecologia enquanto movimento social. Naquela divisão clássica "prática, movimento social, meio acadêmico", a perspectiva espanhola, muito mais que americana, muito mais que a do Gliessman. Gliessman era muito mais acadêmico, nesse sentido. A perspectiva espanhola sempre fez questão de fazer dialogar com a academia com o movimento social. De outro modo, a entrada da literatura francesa ela é um pouco mais estranha, porque ela não se dá pelo termo agroecologia, ela se dá por um conjunto de discussões que tem a ver com o campesinato, a agricultura, depois com a questão ambiental. Na França há uma discussão muito importante de ambientalização da agricultura. Tanto é que muita gente, o próprio Alfio, a Maria José Carneiro, que discutiam agricultura familiar e campesinato, vão somar as suas reflexões à questão ambiental. É, o Jalcione. O Jalcione fez isso ainda muito antes (Paulo Niederle, João Pessoa, 2015).
\end{abstract}


Segundo Niederle, a força cordobesa se dá muito mais no sentido da mobilização social e da militância acadêmica para a intervenção pública do que na produção de evidências científicas, sendo este último fator muito mais característico da França, principalmente nos aspectos sociológicos oriundos das discussões sobre campesinato e ambientalização da agricultura, graças a pesquisadores como Alfio Brandenburg, Maria José Carneiro e Jalcione Almeida. Reiterando:

Quando a gente dialoga com os franceses, você não vê esse processo de institucionalização como a gente tem aqui. A agroecologia não se tornou um termo de política do Estado ainda tão forte na França como é no Brasil. E também não tem essa aderência acadêmica como a gente tem aqui. Se você vai num congresso na França, não tem muita gente falando em agroecologia como a gente faz aqui. Só que a perspectiva com que isso vem se dando na França é muito mais acadêmica do que propriamente um movimento social. Se a gente for comparar, os franceses, nesse caso em relação aos espanhóis, não têm esse vínculo com o movimento social como predomina entre os espanhóis, o que traz algumas vantagens do ponto de vista do diálogo acadêmico, mas uma série de limitações, inclusive no que tange, por exemplo, à institucionalização de políticas públicas. Política pública para agroecologia na França pode acontecer, provavelmente vai acontecer, mas talvez a gente demore para ouvir falar nesses termos (Paulo Niederle, João Pessoa, 2015).

Entretanto, Jalcione Almeida elaborou em outra direção ao analisar a experiência da agroecologia na França. Quando indaguei sobre a absorção da perspectiva científica da agroecologia a partir deste país, especificamente se haveria uma troca de energia actante entre os brasileiros e os franceses neste quesito:

O termo "agroecologia" entrou mais recentemente na França, mas naquela época falávamos muito em agricultura biológica, o equivalente a agricultura alternativa ou agricultura orgânica, que já estavam surgindo no Brasil, ou ainda agricultura biológica - agriculture biologique - em francês. Agroecologia é um termo que chegou mais recentemente, mas já está sendo assumido, já tão falando. O doutorado, não foi um doutorado que acabou me influenciando, por exemplo, para o lado da agroecologia, não foi! Eu permaneci nas variantes alternativas da agricultura, da forma de produzir e se organizar no campo, mas agroecologia sempre foi muito, durante o doutorado e até o final, muito periférica, e eu acabei me envolvendo mais quando eu voltei do doutorado, mais pelo contexto político que estava no Brasil e no Rio Grande do Sul, sobretudo. Então, eu não tive essa influência cordobesa, [...] que é uma perspectiva da agroecologia que acabou tendo uma influência muito forte na agroecologia brasileira, sobretudo e particularmente o pessoal 
mais ligado a Associação Brasileira de Agroecologia (ABA ) (Jalcione Pereira, João Pessoa, 2015).

8. Éric Sabourin realizou seu pósdoutorado entre 1999 e 2000, na Universidade Federal da Paraíba (UFPB), como bolsista do Centre de Coopération Internationale en Recherche Agronomique pour le Développement (Cirad).

9. Centro de Desenvolvimento Agroecológico Sabiá, uma organização não governamental fundada em 1993, que trabalha para a promoção da agricultura familiar (agroflorestal e agroecológica) dentro dos princípios da agroecologia, com sede no Recife.
A problemática da relação entre a Espanha, o Brasil e a França nas definições da agroecologia local se torna mais clara no relato de Éric Sabourin ${ }^{8}$, quando o professor aciona a Espanha como o impacto mais profundo para o nosso campo de visão. Ao ser questionado sobre a possibilidade de influência francesa na construção da perspectiva científica agroecológica do Brasil, Sabourin responde:

Geralmente não tem tanto peso dos pesquisadores. Tem um peso da dinâmica latino-americana, da Espanha e Córdoba mais fortemente no caso das Universidades também, mas no quesito especifico da França, não (Éric Sabourin, Belém, 2015).

Tanto para o Professor Jalcione Almeida, quanto para o pesquisador Éric Sabourin, a partir de suas experiências pessoais de intercâmbio entre Brasil e França, a proposta da agroecologia parece ter ganhado espaço muito mais no contato com os brasileiros que já trabalhavam com essa ideia do que em território francês. Para Jalcione, o contato com a temática ocorreu após o seu retorno ao Rio Grande do Sul, diante de um quadro cultural efervescente para os movimentos alternativos; e, para Sabourin, quando trabalhou na sede paraibana da AS-PTA e no Centro Sabiá ${ }^{~ e m ~ P e r n a m b u c o . ~}$

$\mathrm{Na}$ institucionalização da agroecologia francesa, os pesquisadores não tiveram participação em manifestações ou eventos dos movimentos sociais que passaram a apresentar a agroecologia como diretriz pragmática (Norder, Lamine \& Bellon, 2015). Assim, a experiência da ciência agroecológica na França assume outro formato, digamos de uma ciência mais "neutra", o que, de certa forma, provoca um estranhamento frente ao modelo praticado no Brasil, principalmente no universo da agroecologia.

É interessante observar que, na ciência agroecológica, a militância é algo incrustado e aquelas pessoas que não se atêm a isso acabam por realizar uma atividade incompleta, como se observa na fala do professor Jalcione:

Eu nunca cheguei a ser militante da agroecologia. A agroecologia sempre foi para mim, desde o início, um tema de pesquisa. Talvez um pouco por isso que as pessoas me viam no passado como militante da agricultura alternativa e tal, esperavam me ver como militante da agroecologia, o que eu não fui, não era! E aí que se criou um pouco de certa animosidade, um certo problema entre eu e algumas militâncias da agroecologia (Jalcione Pereira de Almeida, João Pessoa, 2015). 
Ao saberem que a agroecologia no Brasil perpassa a presença de pesquisadores da área em cargos de gestão pública (Abreu, Lamine, Brandenburg, Bellon \& Mazarotto, 2001), as pessoas que participam das redes em sua defesa tornam-se forças geradoras de criatividade e inovações socioculturais, mudanças essas que afetam o comportamento e as expectativas políticas, forçando a abertura de espaços para novos interesses. Com forte sistema simbólico, os participantes da "Armada Cordobesa" são potencializadores de novas formas de fazer política por meio de

tentativas coletivas e organizadas cujo objetivo era propor mudanças, ou até mesmo a possibilidade de construção de uma nova ordem social (Azevedo, 2010: 215).

Sobre essa discussão, vejamos a opinião de Laetícia Jalil, professora da Universidade Federal Rural de Pernambuco, cuja trajetória e atuação estiveram voltadas para agricultura familiar, gênero e agroecologia. Segundo a professora - atuante acadêmica e política na área da agroecologia, participando de várias instituições desde a sua graduação - realmente existe a conformação de uma "Escola" de Córdoba no Brasil. Ao ser questionada sobre os maiores impactos no país de conteúdos franceses ou espanhóis, a professora responde:

\footnotetext{
Da Espanha! Eu nem consigo vislumbrar uma Escola Francesa. Assim, eu vejo, por exemplo, essa coisa de onde você vai, como que você volta. [...] Então eu consigo ver isso claramente, que tem a Escola na Espanha e que essa escola passa a ser traduzida para o Brasil; isso é importante, porque se você não traduz o que está escrito no campo mesmo de você pegar um texto e traduzir, de você pegar um texto e você construir relações, trazer essas pessoas, mandar pessoas, então assim, eu vejo que isso aconteceu muito fortemente com a Espanha. Assim, se você me perguntar uma pessoa, um autor francês, eu não conheço, que discuta agroecologia. Eu sei que tem... Mas eu não consigo identificar uma escola. Nenhuma influência no Brasil (Laetícia Jalil, Recife, 2015).
}

Na França, a noção de agroecologia só ganha espaço a partir de processos de diferenciação entre agricultores orgânicos e de economia solidária. Neste país, os pioneiros da agroecologia foram os movimentos sociais, não havendo inicialmente definições científicas, nem ritos disciplinares rígidos (Abreu, Lamine, Brandenburg, Bellon \& Mazarotto, 2011). Lá, a agricultura ecológica surgiu como movimento de contracultura e crítica à sociedade de consumo.

O pensamento francês marcou uma geração de pesquisadores brasileiros no que se refere à agricultura ecológica e aos debates ambientais, o que não significa, es- 
pecificamente, que a agroecologia tenha sido um tema central dentre as diferentes manifestações da prática agrícola ecologicamente correta na França e, assim, de forte presença no Brasil (Brandenburg, Billaud \& Lamine, 2015). Tem-se, de um lado, pesquisadores como Alfio Brandenburg e sua "Escola Francesa" e, de outro, a atuação de extensionistas como Caporal e Costabeber enquanto participantes da "Escola de Córdoba". Portanto, ambos os direcionamentos encaminham grande parte da produção textual agroecológica.

Sobre essa polaridade, o professor Niederle aponta algumas considerações:

\begin{abstract}
Alfio tem uma importância, do ponto de vista da legitimação da agroecologia no âmbito acadêmico, que, a meu ver, é muito mais expressiva. Por quê? Porque conseguiu dialogar com um conjunto de referenciais teóricos, analíticos, com uma discussão mais ampla de ambientalização que encontrou mais ressonância no meio acadêmico. Do ponto de vista de Caporal e Costabeber, a gente percebe que os textos deles circulam no meio acadêmico, mas eu acho que, comparativamente aos de Alfio, o impacto deles foi muito maior no meio dos policy makers, dos "fazedores de políticas púbicas". Incluindo a participação direta deles na construção de políticas públicas (Paulo Niederle, João Pessoa, 2015).
\end{abstract}

Todavia, observa-se que a influência cordobesa não se dá apenas no engajamento dos pesquisadores, mas também na conformação epistemológica da literatura agroecológica lida e produzida no Brasil, através de pessoas que vão estudar fora, entram em contato com algumas ideias, levando-as de volta para seus países de origem traduzindo textos e espalhando o que aprenderam. Destarte,

parte dos militantes e técnicos mais críticos tiveram em sua formação uma passagem [...] pela Universidade de Córdoba, que privilegia a dimensão política das análises dos processos de transição agroecológica (Abreu \& Bellon, 2014: 9).

Claro que não podemos acreditar num tipo de influência "de baixo para cima", em que a Espanha tenha imposto um modus operandi aos profissionais brasileiros. Todo e qualquer contato envolve troca de energia actante. Porém, o foco deste trabalho é apreender a conformação do cenário brasileiro, de forma a escolher um recorte metodológico que deixa de fora possíveis traços brasileiros na Espanha.

Agora que a agroecologia, enquanto termo, entra no cenário francês muito por influência brasileira e dessas discussões também. Não quer dizer que eles não tivessem discussões similares... Há uma cooperação com a Universidade Federal do Paraná (UFPR/ 
Meio Ambiente), que desenvolve um programa de meio ambiente e desenvolvimento, Alfio, Ângela Damasceno e Magda Zanoni e uma série de grupos franceses, sobretudo num programa que se chama Laboratoire de Dynamiques Sociales et Recomposition des Espaces (Ladyss), que é um laboratório que foi coordenado pelo Hugues Lamarche e agora é coordenado pelo Jean Paul Billaud.

Eles tiveram ao longo dos últimos 20 anos vários intercâmbios nessa discussão socioambiental, não necessariamente agroecologia. É por conta dessa discussão que surgiu esse projeto, que eu comentei no começo e a gente está dando continuidade, digamos assim, ao projeto... O meu reingresso na discussão da agroecologia provavelmente vai se dar por conta do projeto que foi aprovado Brasil-França para os próximos quatro anos que é para estudar a institucionalização da agroecologia em diferentes países (Paulo Niederle, João Pessoa, 2015).

Observamos que a institucionalização da agroecologia no Brasil ${ }^{10}$ ocorreu antes que na França, onde tal proposta ainda se encontra fragmentada. Em contraposição, na França, a agricultura orgânica vem se estruturando desde os anos $1980^{11}$ (Centro de Difusão de Tecnologia do Instituto Agronômico do Paraná, 2013). Lá, a agricultura ecológica, em sua versão da agricultura biológica, se institucionaliza antes do Brasil. Por exemplo, a lei que normatiza agricultura orgânica no Brasil surge em 1999, enquanto na França, surgiu na década de 1980 (Brandenburg, Billaud \& Lamine, 2015).

Na França, a agroecologia somente começou a ser veiculada nacionalmente a partir de 2008, ainda que muito ligada ao setor empresarial da produção agroalimentar, o que difere muito do Brasil, onde ela segue como referência para a agricultura familiar e camponesa. Inclusive, o Institut National de la Recherche Agronomique (Inra), principal instituição francesa de pesquisa agronômica, incluiu a agroecologia em seus eixos prioritários apenas em 2010 e, em 2012, o Ministério da Agricultura anunciou o Programa Produire Autrement, justamente para fomentar a transição agroecológica (Norder, Lamine \& Bellon, 2015).

\section{O retorno ao Brasil e o entrelaçamento com as políticas públicas}

O retorno da "Armada Cordobesa" para o Brasil define muito da constituição do campo científico da agroecologia. Obviamente, estamos diante de um ambiente múltiplo e que se diversifica cada vez mais, com opiniões divergentes acerca de vários aspectos - epistemológicos, teóricos e práticos. Apesar disto, é possível observar regularidades empíricas que ajudam a compreender elementos que fazem diferença no mundo social. Para isto, analisaremos trechos das entrevistas de Fran-
10. Na questão das políticas públicas, o Conselho Nacional de Segurança Alimentar (Consea) foi apresentado como referência da participação entre sociedade civil e governo.

11. Uma experiência de destaque é a da Associação para Manutenção de uma Agricultura Camponesa (Amap), com grande engajamento dos consumidores. Aqui, foca-se na criação de mercados alternativos e a influência entre diversos países. 
cisco Caporal, José Wizniewsky e Eros Mussói, quando estes falam sobre o percurso entre a conclusão de suas pós-graduações e a volta ao lugar de origem.

\begin{abstract}
Quando eu retornei da Espanha, coincidiu com as eleições para diretor técnico da Empresa de Assistência Técnica e Extensão Rural (Emater) e eu participei da campanha e fui eleito diretor técnico. E daí, junto com uma equipe, na época com a assessoria do falecido colega Costabeber - José Antônio Costabeber - a gente implementou a proposta, eu diria assim, na política, uma proposta de extensão rural agroecológica na Emater do Rio Grande do Sul. [...] Isso foi em 1998... 1999! No governo do Olívio Dutra (1999-2002). E daí a gente implementou essa proposta lá e criamos a Revista Agroecologia e Desenvolvimento Rural Sustentável, que existe até agora. Fizemos um Programa de Capacitação em Agroecologia para todos os técnicos de Emater, na época em torno de 1.800 técnicos (Francisco Roberto Caporal, Recife, 2015).
\end{abstract}

Vimos que Caporal procurou ocupar espaços centrais, legitimados, para expandir o novo campo, que perpassa relações dentro e fora do universo acadêmico, fortalecendo-o a partir de vários lugares sociais, isto é, no contato com cargos de mando (diretor técnico da Emater do Rio Grande do Sul) para estabelecer uma proposta voltada para a extensão rural agroecológica e disseminação do saber acumulado - Revista Agroecologia e Desenvolvimento Rural Sustentável e o Programa de Capacitação em Agroecologia.

Os pesquisadores que têm maior prestígio, além de certo capital social, participam de espaços influentes na distribuição de capitais, sendo o capital científico um tipo particular de capital simbólico, fundamentado no reconhecimento dos pares concorrentes do campo científico (Bourdieu, 2004a). Portanto, as relações sociais possibilitam que os atores circulem na esfera política, onde o interconhecimento é a base das relações, legitimando o grupo e o produto acadêmico por ele realizado, cujo o resultado é um trabalho mútuo de legitimação daquele universo de reconhecimento.

Assim, Caporal e seu grupo acumularam capital social (por meio de suas relações interpessoais) e científico (em suas trajetórias dedicadas à agroecologia, com textos que passaram a ter grande circulação nas universidades), o que permitiu montar um aparato laboratorial para estudos que serão acompanhados de um trabalho simbólico de reconhecimento do objeto de pesquisa pelos semelhantes, induzindo legitimidade. Isto nos leva a inferir que a escolha científica é uma estratégia política orientada para a obtenção do reconhecimento dos pares do campo e para a sociedade no geral, já que o campo científico é um lugar de luta pela dominação científica, o que indica a possibilidade de métodos, estratégias e projetos políticos do pesquisador (Cavalcanti, 2010). 
Quando abre uma oportunidade política no governo do Rio Grande do Sul, mais especificamente na eleição que Olívio Dutra ganhou, em 1999, que ele por influência de parte dessa turma que resolve fazer a extensão rural agroecológica, é um enorme espaço [...]. Como político [Olívio Dutra], estava no movimento sindical, era do sindicato dos bancários. Torna-se governador, monta uma equipe bastante inovadora e faz - para mim - a única e primeira experiência consistente de agroecologia. [...] O primeiro congresso foi lá. Então isso preconiza as pessoas irem se conhecendo e começaram a se chamar. Eu mesmo fui chamado - apesar de ser gaúcho, estava em Santa Catarina - para apoiar o governo Dutra; ia lá, dava cursos, participava com o pessoal, e muitos outros. Então, no Rio Grande do Sul, para mim, foi o primeiro momento que profissionais, alguns curiosos, outros com mais conhecimento da agroecologia se inseriram nas políticas públicas, passaram seja pela informação e formação de pessoas, seja pela área propriamente técnica, seja pela pesquisa (Eros Mussói, Belém, 2015).

O interessante é que grande parte da institucionalização da agroecologia é centrada na extensão rural e, consequentemente, na agronomia, áreas que delimitam os princípios e o potencial da agroecologia. É importante frisar que não existe um movimento unilinear na passagem de acadêmicos para gestores públicos. Em outras palavras, o fluxo de atores não é somente da academia para o espaço público, mas envolve movimentos diversos, que, no fim, apontam para uma mesma tendência, a da ciência engajada.

Caporal voltou em 1998 e assumiu em 1999. Olívio Dutra tinha ganhado o governo do Estado [...]. E antes tinha muito apoio dos movimentos sociais, a ideia era criar referência, essa era a grande perspectiva da Emater: criar referências em agroecologia (José Geraldo Wizniewsky, João Pessoa, 2015).

A professora Maria Virgínia, ao retornar da Espanha para o Brasil, recebeu o convite para trabalhar na Federação de Órgãos para Assistência Social e Educacional (Fase), instituição de grande importância na institucionalização prática da agroecologia, o que significa que ela já conhecia anteriormente o grupo da Fase por meio de suas posições análogas no espaço social, ou seja, de pessoas focadas num mesmo tipo de fazer acadêmico e de trajetória profissional, voltada para o mundo rural e para os movimentos sociais. Como ela mesma afirma, o seu convite não foi feito por uma pessoa, mas sim por um coletivo, ela reencontra o grupo de Córdoba, com quem já havia mantido contato durante a graduação e cuja estrutura do campo sempre os aproximava, isto é, a abertura política e o fortalecimento da pauta ambiental no Rio Grande do Sul, assim como tudo o que acontece na sociedade de rede, onde as ações sociais são geradas a partir das conexões entre os atores. 
É importante considerar a influência filosófica, política e técnica da "Armada Cordobesa" na Associação Brasileira de Agroecologia (ABA), o principal coletivo acadêmico de agroecologistas a realizar congressos e a organizar publicações em torno da temática, isto é, uma força paradigmática bem definida e que gera energia actante, tendo como um dos principais porta-vozes Caporal que, quando retornou do doutorado, estabeleceu-se como ator-chave e elo capaz de agrupar uma série de outros atores na construção de iniciativas agroecológicas.

As estratégias utilizadas nas lutas simbólicas do campo científico dependem das posições dos atores sociais, sendo orientadas ou para a conservação da estrutura ou para a sua transformação. Quanto mais favorecida é a posição de um ator na estrutura, maior a tendência para querer conservá-la (Bourdieu, 2004a). Assim, os agroecologistas, enquanto defensores de um novo fazer acadêmico, tentam a todo custo transformar a estrutura das relações entre cientistas e agricultores, posicionados contra os profissionais (pesquisadores e extensionistas) de todas as áreas, mas, principalmente, da agronomia, por representarem os atores conservadores e estabelecidos, os quais ainda se apegam à atividade cartesiana e difusionista.

Esse campo interioriza um jogo de discussão e de diálogo, na tentativa de atribuir caráter científico aos fatos trabalhados. O conhecimento não se assenta em evidências subjetivas de um indivíduo isolado, mas na experiência coletiva regulada por normas de comunicação e argumentação. Portanto, o fato é construído e conquistado pela comunicação dialética dentro do processo de produção coletiva da verdade.

A conformação do cenário agroecológico nacional envolve a combinação de diferentes capacidades com um objetivo relativamente coeso, reunindo pessoas com interesses significativos em círculos formais e informais que abrangem a elite acadêmica, pesquisadores e pessoas fora do campo acadêmico.

\footnotetext{
Eu falo muito que quando chego num lugar que eu não conheço ninguém, estou no lugar errado, entendeu? Eu chego num congresso, eu digo "não tem ninguém aqui?" Eu digo "hmm, festa estranha com gente esquisita", porque você já tem certa trajetória. Então, assim, você chegar num lugar que você não tem nenhum ponto de conexão, nenhuma rede, você não consegue identificar um nó que te liga ali, você está no lugar errado. Então isso é um campo que a gente tem que reconhecer. Então essas pessoas, esses pesquisadores que estão aí discutindo agroecologia dentro da academia ou nas ONGs ou no Estado também ou enfim, a gente se conhece, não é? [...] Hoje, claramente, eu chego numa reunião da Articulação Nacional de Agroecologia (ANA), eu posso não conhecer todo mundo, mas você já ouviu falar, você reconhece aquela
} 
pessoa que também está no campo agroecológico e ele vai ser um agricultor, uma agricultora, vai ser uma pesquisadora (Laetícia Jalil, Recife, 2015).

Um ponto de vista é uma visão a partir de uma posição particular no espaço. Um ponto de vista é também um ponto no espaço onde nos colocamos para obter uma determinada visão (Bourdieu, 2004b). Portanto, as trajetórias dos agroecologistas, por mais diversas que sejam, apontam para um engajamento político-científico focado na transformação do espaço acadêmico e das políticas governamentais voltadas para o campo.

\section{Considerações finais}

O campo acadêmico pode ser entendido como um lócus de relações cujos protagonistas são produtores de conhecimento acadêmico. Neste campo, há uma bataIha para classificar o que pertence ou não a este mundo. Trata-se de um universo específico de práticas dentro de um aparato institucional no âmbito do qual as lutas visam conservar ou transformar os critérios que o compõe, um jogo pela garantia da produção da crença e pela representação socialmente reconhecida como científica.

A trajetória da formação acadêmica e o prestígio político determinam muito da posição privilegiada do ator, isto porque a notoriedade enquanto pesquisador se associa à posse de capital político, no mais, capital político e capital acadêmico se reforçam mutuamente. O destaque dos atores se dá também pelo

capital social que é pertinente à rede de relações estabelecidas durante a trajetória de formação acadêmica e profissional, principalmente marcada por um tipo de circulação internacional. [Essa rede cria um] novo espaço de poder, em que experts em governabilidade, pertencentes a um mercado internacional, imprimem diretrizes políticas no âmbito local (Hey, 2008: 40 e 43),

atuando como técnico-políticos, provenientes do universo acadêmico, o que legitima suas ações políticas.

Portanto, alguns atores, estrategicamente posicionados, são mais ativos no discurso agroecológico e são essas pessoas - que têm em comum o fato de serem qualificados nos debates que envolvem o mundo rural e, assim, passaram a atuar no espaço político em benefício da produção de ideias sobre o mundo social e a realização prática dessas ideias - que foram escolhidas para darem seus depoimentos nesta pesquisa. 
Está claro que "a evolução da agroecologia depende da força da interação entre movimentos sociais, redes científicas e da construção de políticas públicas" (Abreu, Bellon \& Torres, 2016: 1). Nesse ínterim, o cenário científico agroecológico une um sistema informal de contatos transdisciplinares que liga as pesquisas acadêmicas, a prática docente e as atividades de extensão de diferentes pessoas interessadas, o que produz um movimento de autolegitimação. Isso permite desenvolver o novo campo sem que haja, necessariamente, uma cátedra totalmente reconhecida por todos os cientistas que estudam o mundo rural.

\section{Referências}

ABREU, Lucimar S. de; BELLON, Stéphane. "A dinâmica do desenvolvimento a agroecologia no Brasil e na América Latina". Trabalho Apresentado no VI Encontro da Rede de Estudos Rurais. Campinas (SP): Unicamp, 2014.

ABREU, Lucimar S. de; BELLON, Stéphane; TORRES, Tércia Z. A contribuição das ciências e do movimento social para a agroecologia no Brasil. ComCiência, n. 182, 2016.

ABREU, Lucimar S. de; LAMINE, Claire; BRANDENBURG, Alfio; BELLON, Stéphane; MAZAROTTO, Angelo A. V. de Sá. "Agroecologia, movimento social, ciência, práticas e políticas publicas: uma abordagem comparativa". Resumo apresentado no VII Congresso Brasileiro de Agroecologia. Fortaleza (CE), 12/16 Dez. 2011.

ALMEIDA, S. G. de. Construção e desafios do campo agroecológico brasileiro. In: PETERSEN, Paulo (Org.). Revista Agriculturas - Experiências em Agroecologia. Agricultura familiar camponesa na construção do futuro. Rio de Janeiro: AS-PTA, 2009.

ALTIERI, Miguel; TOLEDO, Victor M. The agroecological revolution in Latin America: rescuing nature, ensuring food sovereignty and empowering peasants. The Journal of Peasants Studies, v. 38, n. 3, p. 587-612, Jul. 2011.

AZEVEDO, Daviane Aparecida de. Movimentos sociais, sociedade civil e transformação social no Brasil. Saber Acadêmico. Revista Multidisciplinar da Uniesp, n. 9, Jun. 2010.

AZEVEDO, Edisio Oliveira. Desafios e perspectivas da Agroecologia. In: CAPORAL, Francisco Roberto; AZEVEDO, Edisio Oliveira (Orgs.). Princípios e perspectivas da agroecologia. Curitiba: Instituto Federal de Educação, Ciência e Tecnologia do Paraná - Educação a distância, 2011.

. A ilusão biográfica. In: FERREIRA, Marieta de Moraes; AMADO, Janaina (Orgs.). Usos \& abusos da história oral. 8. ed, p. 183-191. Rio de Janeiro: Editora FGV, 2006. 
- Os usos sociais da ciência: por uma sociologia clínica do campo científico. São Paulo: Editora Unesp, 2004a.

. Para uma sociologia da ciência. Lisboa: Edições 70, 2004b.

BOURDIEU, Pierre. A ilusão biográfica. In: FERREIRA, Marieta de Moraes; AMADO, Janaina (Orgs.). Usos \& abusos da história oral. 8. ed, p. 183-191. Rio de Janeiro: Editora FGV, 2006.

. Os usos sociais da ciência: por uma sociologia clínica do campo científico. São Paulo: Editora Unesp, 2004a.

Para uma sociologia da ciência. Lisboa: Edições 70, 2004b.

BRAGA, Ruy. O pêndulo de Marx: sociologias públicas e engajamento social. In: BRAGA, Ruy. Por uma sociologia pública. São Paulo: Alameda, 2009.

BRANDENBURG, Alfio. Movimento agroecológico: trajetória, contradições e perspectivas. Desenvolvimento e Meio Ambiente, n. 6, p. 11-28, Jul./Dez. 2002.

BRANDENBURG, Alfio; BILLAUD, Jean-Paul; LAMINE, Claire. Apresentação - A agricultura ecológica e as redes agroecológicas. In: BRANDENBURG, Alfio; BILLAUD, Jean-Paul; LAMINE, Claire (Orgs.) Redes de agroecologia: experiências no Brasil e na França. Curitiba: Kairós Ediç̧̃es, 2015.

CAPORAL, Francisco Roberto; COSTABEBER, José Antônio; PAULUS, Gervásio. Agroecologia: matriz disciplinar ou novo paradigma para o desenvolvimento rural sustentável. In.: CAPORAL, Francisco Roberto; AZEVEDO, Edisio Oliveira (Orgs.). Princípios e perspectivas da agroecologia. Curitiba: Instituto Federal de Educação, Ciência e Tecnologia do Paraná - Educação a distância, 2011.

CAVALCANTI, Valesca Marques. Ciência, modernidade, tecnologia e natureza: uma análise sobre o desenvolvimento do algodão naturalmente colorido na Paraíba. Dissertação (Mestrado em Ciências Sociais) - Programa de Pós-Graduação em Ciências Sociais (PPGCS), Universidade Federal de Campina Grande (UFCG), Campina Grande (PB), 2010.

CENTRO DE DIFUSÃO DE TECNOLOGIA (CDT), INSTITUTO AGRONÔMICO DO PARANÁ (IAPAR). Relato do I Seminário de Agroecologia Brasil x França. I Seminário de Agroecologia Brasil x França. Londrina (PR), 5/6 Dez. 2013. Disponível em: <http://200.201.27.34/agroecol/material/Relato\%20do\%20l\%20Seminario\%20 de\%20Agroecologia\%20Brasil\%20Franca\%20-\%20IAPAR.pdf>. Acessado em: 6 Ago. 2015. 
FAGUNDES, Alessander Von Wagner; LADIERA, Isabela Fabiana da Silva; OLIVEIRA, Lara Angelo. 2013. O processo de organização dos grupos de agroecologia no Brasil. Cadernos de Agroecologia, v. 8, n. 2, Nov. 2013.

HEY, Ana Paula. Esboço de uma sociologia do campo acadêmico: a educação superior no Brasil. São Carlos: EdUFSCar, 2008.

LATOUR, Bruno. Reagregando o social. Salvador; Bauru (SP): Editora UFBA; Edusc, 2012.

- Políticas da natureza: como fazer ciência na democracia. Bauru (SP): Editora UFSCar, 2004.

—. Ciência em ação. São Paulo: Editora Unesp, 2000.

LEFF, Enrique. Racionalidade ambiental: a reapropriação social da natureza. Rio de Janeiro: Civilização Brasileira, 2006.

LUZZI, Nilsa. O debate agroecológico no Brasil: uma construção a partir de diferentes atores sociais. Tese (Doutorado) - Programa de Pós-Graduação em Desenvolvimento, Agricultura e Sociedade, Universidade Federal Rural do Rio de Janeiro, Seropédica (RJ), 2007.

NORDER, Luiz Antonio; LAMINE, Claire; BELLON, Stéphane. Agroecologia: polissemia, pluralismo e controvérsias. In: BRANDENBURG, Alfio; BILLAUD, Jean-Paul; LAMINE, Claire (Orgs.). Redes de agroecologia: experiências no Brasil e na França. Curitiba: Kairós Edições, 2015.

PADULA, Juliana; CARDOSO, Irene Maria; FERRARI, Eugênio Alvarenga; DAL SOGLIO, Fabio Kessler. Os caminhos da agroecologia no Brasil. In: GOMES, João Carlos Costa; ASSIS, William Santos de (Orgs.). Agroecologia: princípios e reflexões conceituais. Brasília: Embrapa, 2013.

PAULINO, Jonatta S. O campo científico e a agroecologia no Brasil: atores, discursos e políticas públicas. Tese (Doutorado em Ciências Sociais) - Programa de Pós-Graduação em Ciências Sociais (PPGCS) da Universidade Federal de Campina Grande (UFCG), Campina Grande (PB), 2017.

— Modernidade e ciência: tensões do discurso agroecológico. Dissertação (Mestrado em Ciências Sociais) - Programa de Pós-Graduação em Ciências Sociais (PPGCS), Universidade Federal de Campina Grande (UFCG), Campina Grande (PB), 2013. 
PETERSEN, Paulo; DAL SOGLIO, Fábio. K.; CAPORAL, Francisco. R. A construção de uma ciência a serviço do campesinato. In: PETERSEN, Paulo (Org.). Revista Agriculturas - Experiências em Agroecologia. Agricultura familiar camponesa na construção do futuro. Rio de Janeiro: AS-PTA, 2009.

SAID, Edward W. Cultura e imperialismo. São Paulo: Companhia das Letras, 2011.

WEID, Jean Marc von der $(1985,1988)$ apud BRANDENBURG, Alfio. Apresentação - Os agricultores ecológicos e a (re)construção do ambiente rural. In: BRANDENBURG, Alfio e FERREIRA, Angela D. Damasceno (Orgs.). Agricultores agroecológicos e o ambiente rural: visões interdisciplinares. São Paulo: Annablume; Cnpq; Petrobras, 2012. 
